\title{
Is Tourism in Zimbabwe Developing with the Poor in Mind? Assessing the Pro-poor Involvement of Tourism Operators Located Near Rural Areas in Zimbabwe
}

\author{
Sarudzai Mutana ${ }^{1}$, Tsitsi Chipfuva ${ }^{2} \&$ Blessing Muchenje $^{1}$ \\ ${ }^{1}$ Department of Tourism, Leisure and Hospitality Studies, Faculty of Commerce, University of Zimbabwe, \\ Zimbabwe \\ ${ }^{2}$ Botswana Accountancy College, University of Derby, Gaborone, Botswana \\ Correspondence: Sarudzai Mutana, Department of Tourism, Leisure and Hospitality Studies, Faculty of \\ Commerce, University of Zimbabwe, Zimbabwe. E-mail: mutanasimangos@gmail.com
}

\author{
Received: February 27, 2013 Accepted: April 12, 2013 Online Published: April 27, 2013 \\ doi:10.5539/ass.v9n5p154 URL: http://dx.doi.org/10.5539/ass.v9n5p154
}

\begin{abstract}
The paper explores the contribution of tourism industry operators to pro-poor tourism development in Zimbabwe. This research investigates a possible nexus between the aforementioned tourism growth and its potential for poverty reduction in communities surrounding Victoria Falls and Hwange. The researchers conducted semi-structured interviews with tourism industry businesses that exhibited their products and services at the International Travel Expo held on the $18^{\text {th- }} 21^{\text {st }}$ of October 2012 at the Harare International Conference Centre in Zimbabwe. Findings indicate that the tourism industry is keen to engage in pro-poor tourism initiatives for the rural people despite the political and economic turmoil that the industry has suffered over the past years. In Zimbabwe, $80 \%$ of the population resides in rural areas and a sizable fraction of these are near National Parks and Tourism Resorts, for example, Hwange National Park, the biggest Park in Zimbabwe and Victoria Falls, respectively. The findings point to the fact that tourism operators appreciate the need to incorporate pro-poor initiatives in their operations as evidenced by their commitment towards education funding initiatives, employment of the poor and generation of income from village tours. However more could be done to enhance the pro-poor tourism benefits that accrue to the rural poor by establishing close linkages between tourism operators and local communities.
\end{abstract}

Keywords: pro-poor, tourism, stakeholders, poverty alleviation, rural tourism

\section{Introduction}

\subsection{Tourism Development in Zimbabwe}

Muchapondwa and Pimhidzai (2008) mentioned that Zimbabwe's tourism figures began to decline in 2000 because of political instability that is attributed to controversies regarding the draft constitution, land reform and the outcome of the parliamentary elections in 2002. In addition they also mention that international arrivals registered $4.5 \%$ decline for the period 2000 to 2005 with the largest annual declines being $14.7 \%$ and $15.9 \%$ in 2003 and 2005 respectively (Muchapondwa \& Pimhidzai 2008). Resultantly, a negative image on Zimbabwe rose in major source markets most of whom issued travel warnings against Zimbabwe (Manwa, 2007). After the Land Reforms and the obvious reduction in tourism receipts and arrivals, the government launched the Look East policy in a bid to increase tourism activity (Mkono, 2010). This had an insignificant positive impact as the policy resulted in the attraction of low spending tourists from China, Japan and other Asian countries compared to the traditional western markets of German, USA, France and Australia. It was clear that without a more stable political environment, the tourism sector would continually face challenges in trying to grow (Mkono 2010).

However the Global Political Agreement has brought political stability which is slowly changing the country's tourism fortunes as indicated by the tourism statistical performances. According to Mushawevato, (2012) tourism contributed $10.3 \%$ to Gross Domestic Product (GDP) of the country in 2011, and was the second income earner after mining. Additionally the World Tourism Council has forecasted that if the country remains politically stable, in 2012 tourism will grow by $8.7 \%$ annually compared to the $10 \%$ growth rate for China which is in pole position (Mushawevato, 2012). Although the country is due for elections in 2014, it is apparent that tourism 
growth is positive and the Ministry of Tourism and Hospitality is forecasting that Zimbabwe should become the second largest destination in Southern Africa, after South Africa. The forecasted growth is an indication that tourism development can be tapped to provide a wealth of opportunities for people in rural areas. Furthermore Zimbabwe will be hosting the $25^{\text {th }}$ Edition of the UNWTO Conference in Victoria Falls in August 2013, a move which is expected to further improve the performance of the tourism sector in Zimbabwe.

Rural tourism in Zimbabwe has been contextualized through the Communal Areas Management Programmes for Indigenous Resources CAMPFIRE (Logan \& Mosely (2010) which was jointly developed by the Government of Zimbabwe and United States Agency for International Development (USAID). The programme aimed to convince communities that wildlife is not an impediment to rural agricultural production (Logan and Mosely, 2010) but a source of livelihood for rural people. The communities involved in CAMPFIRE generated revenue through trophy hunting, nature tourism, live animal sales and meat cropping (Logan \& Mosely, 2010). The economic and political crisis in Zimbabwe however impacted negatively on CAMPFIRE. Bad publicity reduced non-consumptive tourism, and, hunting revenue declined and the government's policy of significantly overpricing the Zimbabwe dollar in official exchange rates led to devaluing CAMPFIRE receipts (Muir-Leresche et al., 2003 as cited in Logan and Mosely, 2010). In addition despite the political turmoil CAMPFIRE could have become a viable tool for rural development if it had followed its initial aim (Hasler, 1995). Its detriment was over-emphasis on conservation which ended up in 'participation" instead of 'involvement' of rural people in the planning of the projects (Garrod, 1992; Muchapondwa, 1998; Hasler, 1995). The resulting confrontation between the conservation authorities and the communities led to the later perceiving interests of conservation to be contrary to community development (Child, 2004).

\subsection{Poverty and the Developing World: A Contextual Definition}

McCullock et al (2001:38) indicates that poverty includes low incomes, low levels of wealth, poor environments, little or no education and vulnerability. The United Nations (2001 p 1) in Ludi and Bird (2007) note that

"Poverty has various manifestations including lack of income and productive resources, sufficient to ensure sustainable livelihood, hunger and malnutrition, ill-health, limited or lack of access to education and other basic services, increased morbidity and mortality from illness, homelessness and inadequate housing, unsafe environments and social discrimination and exclusion from decision making"

Research indicates that whether one is in the developed or developing world, poverty is rather relative and a single definition fails to address all the aspects of poverty as viewed from different geographical locations in the world (Chikwanha-Dzenga 1999, Kinsey, 2010, Nyathi, 2012). The general definition of a poor person as "one who lives on less than a dollar a day" may not apply in some parts of the developing world since one is likely to meet extreme cases of poverty. In Zimbabwe, poverty is defined as the "inability to afford a defined basket of consumption items (food and non-food) which are necessary to sustain life (Poverty Assessment Study Survey 1996: iii), lack of access to the necessary draught power (Manyena, 2003, Nyathi,2012) safe drinking water and sanitary and health facilities (Lurdi \& Bird, 2007). Manjengwa, Kasiyre and Matema, (2012) noted that 81.6\% of population in 16 surveyed districts were below the total poverty line in 2011 with the majority of the poor are in rural areas-where $95 \%$ are below the total poverty line as shown in Table 1 below.

Table 1. Poverty incidence in Zimbabwe (2011) (ZIMSTAT as cited in Manjengwa, Kasiyre and Matema, 2012)

\begin{tabular}{lclllll}
\hline & All Poor & & & \multicolumn{3}{c}{ Very Poor } \\
\hline & All & Urban & Rural & All & Urban & Rural \\
Poverty Incidence (\%) & 81.6 & 62.6 & 95.1 & 44.4 & 8.5 & 68.3 \\
Poverty Depth (\%) & 52.8 & 27.2 & 71.1 & 20.6 & 2.3 & 33.6 \\
Poverty Severity (\%) & 39.2 & 14.9 & 56.7 & 21.1 & 0.9 & 19.4 \\
Number of households & 3,448 & 1,436 & 2,012 & 1,497 & 122 & 1,375 \\
\hline
\end{tabular}

Although many authors concur that poverty definitions are relative and elusive, UN (2002) and Kinsey, (2010,) said there is a general consensus on the fact that poverty in most developing countries is associated with rurality. Kinsey (2010) further notes that poverty in Zimbabwe is overwhelmingly rural, yet the rural areas accommodate over two thirds of the population. $77 \%$ of the poor people are found in these rural areas and this account for $90 \%$ 
of the extremely poor population (Kinsey, 2010). Given the high incidence of poverty levels in rural Zimbabwe it is important to tap the opportunities presented by tourism to alleviate poverty. Chikwanha-Dzenga (1999) while describing poverty in the Zimbabwean context, notes that the rural folk in Zimbabwe have come to rely on 'welfarism' as a solution to their economic crisis. She also goes on to simplify the contextual definition of poverty by saying that people are considered to be poor when their time and efforts are devoted to issues concerning basic survival, and at times lack of knowledge on how to organise for better resource mobilisation. However this paper adopts the definition of poverty as those people who live under less than one US\$ per day.

\subsection{Tourism and Poverty Alleviation}

Pro-poor tourism is defined as tourism that generates net benefits to the poor (Ashley \& Roe, 2010). Poverty reduction is not usually at the heart of the tourism agenda (Ashley, Roe \& Goodwin, 2001), yet tourism is significant in many poor countries and is already affecting the livelihoods of millions of people negatively and positively. The British Department of International Development (DFID) was the first agency to promote the concept of pro-poor tourism. The concept was successfully incorporated in the report of the Commission on Sustainable Development in 1999. The Pro-poor tourism approach later received wider support within the UWTO paper on poverty alleviation and tourism which was released at the World Summit on Sustainable Development which took place in Johannesburg in 2002 (UWTO,2002). During this summit, the UWTO launched a new research programme called Sustainable Tourism Eliminating Poverty (STEP) whose objective was to attract investment for focussed research investigating causal relationships and tourism models that link tourism and poverty alleviation (Lurman, 2002). Tourism's potential role in poverty alleviation hinges on the diversity of the industry, inseparability of the product, intensive labour requirements and tourism's reliance on natural resources such as wildlife and culture which are the poor's assets (Ashley \& Mitchel, 2009). Goodwin (2010) acknowledges Ashley and Mitchel (2009)'s notion that there are three pathways by which the benefits and costs from tourism can be transmitted to the poor

1) Direct effects including income and non-financial livelihood changes for example improved infrastructure,

2) Secondary effects and induced effects and indirect earnings in non-tourism sectors for example farming and crafts

3) Dynamic effects, which influence long term changes in the economy and patterns of growth.

Since the 1990s, tourism as an instrument to reduce poverty has been an important research topic, particularly in developing countries (Ryan \& Xeng, 2012). Agriculture and mining, have suffered adverse shocks in the past, due to environmental degradation and fragile ecosystems, lack of access to agricultural markets and deteriorating terms of trade of African agricultural exports and thus tourism appears to be relatively less vulnerable than other sectors (Gerosa, 2003). This explains African countries' pursuance of the pro-poor agenda of tourism development. The international tourism industry is believed to generate economic and other benefits for poor people and communities sustainably and thus serves as an instrument to help achieve the Millennium Development Goals (MDGs) by 2015 (UNDP, 2011a). However in Africa tourism has been excluded in poverty reduction policies and only a few countries have Tourism Master Plans and therefore potentialities of tourism for wealth creation and redistribution in poor areas have not been fully exploited (Gerosa, 2003). Despite the anticipated benefits for local communities, Ashley and Mitchel (2009) warn that there is little or no evidence about how the different types of tourism impact the poor, yet it is clear that not all types of tourism can have the same impacts on the poor. Renard, Darchevile and Krishnayaran (2001) concur that poverty alleviation through tourism development is not automatic because of uneven distribution of tourism resources, difficulties in accessing common property assets, exclusion of the poor in decision making and a lack of knowledge on the tourism industry. In addition Pluss and Backes (2002, as cited in Chok et al., 2007) argued that tourism cannot be used as a tool for poverty alleviation because in 10 out of the 13 countries in which $80 \%$ of the poor reside, tourism has been an ineffective tool for poverty alleviation. Therefore there is doubt as to whether tourism can be useful as an agent of poverty alleviation in Zimbabwe. Farrell and Twinning-Ward (2005) contend that pro-poor tourism is not an effective means for poverty alleviation because of the seasonality of tourism. The tourism industry in Zimbabwe is characterised by peaks and troughs and therefore its immense contribution to poverty alleviation is not guaranteed. Commercial synergies between private operators and rural communities are more often than not characterized by unbalanced socio-economic relations which disadvantage the poor (Cooper, 2003; Mbaiwa, 2004; Mowforth \& Munt, 2003; Reid, 2003, as cited in Chok et al., 2007).

\section{Methodology}

Semi-structured interviews were carried out with 10 lodges and 10 tour operators operating in Victoria Falls, Hwange that exhibited at the International Expo. Altogether there are approximately 30 tour operators and 50 
lodges in Hwange and Victoria Falls. Representatives of organisations operating in these areas were engaged on the side-lines of the October 2012 Sanganai/ Hlanganani Travel Expo in Harare. The respondents are in managerial positions in their organisations and therefore had the authority to speak on behalf of their organisations. Additionally they also had information about their organisation's activities. $25 \%$ of the respondents were owners of Small to Medium tour operators operating in the above mentioned areas while $75 \%$ were managers from accommodation establishments. Apart from the first few demographically related questions which sought to establish the nature of tourism business the organisation was engaged in, most of the questions were generally open ended to allow respondents to give as much information as was possible for example "how is the level of poverty in rural areas around your lodge or the place you operate?". The researchers would also probe for further explanations on responses given. Responses were audio taped and ten translated literally. Data was analysed manually using content analysis to pick recurrent responses and recording frequencies. The researchers then interpreted the data to come up with conclusions.

\section{Findings and Discussion}

\subsection{Poverty Level in Communities}

When asked to rate the level of poverty in the areas around them, $85 \%$ of respondents indicated that the rural communities around their operations were extremely poor (living on less than a dollar a day, while $15 \%$ indicated that the communities were poor (living on less than $\$ 2$ a day. The situation qualified for what Gordon (2005) referred to as 'absolute poverty' which a condition characterised by severe deprivation of basic human needs including food, safe drinking water, sanitation facilities education and information. This affirms the assertion by Scheyvens, (1999) that a geographical overlap exists between areas of high tourism activity and poverty. This situation can be linked with Shaw and Williams's (1998 p 35) view that the use of rural areas by tourism operators and urban dwellers remain highly contingent and as such rural areas remain extremely underdeveloped. This situation calls for what Ashley and Roe, (2010) called 'putting poverty at the heart of the tourism agenda' by adopting a pro-poor tourism approach. Respondents indicated that rural areas around their operations depicted characteristic of social underdevelopment, indicated by low knowledge of health issues and very low levels of education, very little or no source of income and high levels of reliance on NGOs for food, clothes, education and livelihood. Kinsey (2010) describes this situation as the evidence of extreme poverty. In the Limpopo Province of South Africa, before the introduction of the pro-poor tourism initiatives adopted by government and the private sector (Mafunzwaini \& Hugo 2001) discovered the same levels of poverty.

\subsection{Level of Involvement in Pro-poor Tourism}

The findings of this research show a paradigm shift from Ashley 's findings in 2001 that generally poverty reduction is not at the heart of the tourism agenda, as $75 \%$ of the organisations included in the survey have adopted a pro-poor approach to their operations. $90 \%$ of the organisations employ from the local areas although most of the jobs are basically menial in nature with locals failing to compete for the more paying jobs which need more training and education. The majority of the local employees employed in the lodges and tour operators are employed as cleaners, room maids, grounds men, security guards and porters (55\%), chefs, waiters, guides, cultural dancers and drivers $(40 \%)$, supervisors $(10 \%)$ and middle to top management $(5 \%)$. This concurs with Mbaiwa (2005)'s findings in the Okavango Delta where he found out that in the Okavango Delta, the jobs occupied by local people in the tourism sector are menial lowly paid jobs. The low level jobs held by the local people are congruent to their lower levels of education. The same sentiments were echoed by UNWTO (2005) who mentioned one of the obstacles to the employment of the poor to be absence of education and training. Therefore it is important for the tourism enterprises to develop tourism education and training programmes to support the poor's employment in higher positions. In $25 \%$ of cases, the owners of the tour operating companies surveyed are from the local community, and have adopted a pro-poor approach to doing tourism business, since they also benefitted from similar initiatives introduced by a tour operating company in their area as they grew up.

Tourism organisations which include Shearwater, People Link Tours, African Coast Travel and Tours among other operators have built school blocks in three primary schools and 1 vocational technical college in Victoria Falls through encouraging volunteerism among tourists as well as donations. In Hwange, one tour operating organisation has teamed up with a Non-governmental organisation to build school blocks for 2 primary schools and 1 secondary school. The building of blocks at schools go a long way in addressing poverty issues since lack of basic education is one indicator of extreme poverty and one that has a ripple effect. In Zimbabwe, Matebeleland North province, which is the tourism cash cow, has the least numbers of schools. In certain areas, for example Chidobe and Monde communal areas near Victoria Falls, children can walk for 10 to 15 kilometres before they get to a nearest primary school. One can therefore hail the tourism organisations for constructing 
school blocks. Building schools and classroom blocks is one of the pro-poor tourism initiative identified by Ashley, Roe and Goodwin (2001). In addition in Hwange, the lodge operators in partnership with a Non-governmental organisation have donated bicycles to secondary school pupils in view of the long distances the children have to walk to school every day. The long distances have in the past resulted in a number of school drop-outs.

Paying for school fees is one of the most common interventions noted in this research. 95\% of the organisations interviewed have paid school fees for primary school children. This intervention is critical since most of the poor families in the poor rural areas cannot afford to pay school fees for their children. As noted by Chikwanha-Dzenga (1999) extremely poor people are primarily concerned about basic survival. Anything beyond that is luxury and that would include the paying of school fees.

Some of the activities carried out by tourism players surveyed include buying beds for teachers. With Zimbabwe just recovering from period of economic meltdown which was associated with very poor standards of living, low pays and high rates of inflation, some sectors of the country are yet to recover from the adverse impacts of that period. The education sector and the civil service as a whole are still struggling to pay employees a decent salary. In order to ensure that qualified teachers are attracted and retained at specific schools in the Monde and Chidobe community, a certain tour operating company has facilitated the donation of beds for teachers. As indicated by Lepp (2001), rural areas usually lag behind in terms of development due to the inability of rural people to raise their voices high enough to command resources for development, while Hyttienen, (2000) links under-development of rural areas to rural-urban migration among other things.

Some organisations surveyed promoted the community by selling their crafts at their lodges and hotels $15 \%$ of lodges and hotels indicated that they have gift shops at the lodges where locals bring their craft and collect the money once the craft is purchased. There is a need to expand such linkages where the tourism and hospitality businesses can source products from the local community. Linkages could be established with local farmers so that local tourism and hospitality businesses can buy produce from local farmers. The Umngazi River Bungalows in South Africa buys local produce from local farmers and Sun City Resort also buys from local community (Ashley \& Haysom, 2008)

All the surveyed tour operators in Victoria Falls indicated that they do village tours in Monde, Mpisi and Chidobe communities. The objective of these village tours is to increase awareness of how people are living in the community and give the tourists a chance to assist the locals. One tour operator has constructed a cultural village in Mpisi village where groups of tourists go to experience the culture of the Mpisi people in a staged environment. Although some authors have criticised these types of tours which are called "reality tours' or 'poverty tours', these tours have helped the communities near Victoria Falls and Hwange by reducing poverty. Although the tourists are discouraged from giving money and items to locals, many tourists have come back as volunteers in construction of school blocks, or donated clothes, building material land schools uniforms after such tours.

A well- known Safari Lodge in Victoria Falls has constructed a cultural restaurant where the setting within the cultural restaurant had sitting arrangements of guests allocated to clusters named after the local villages of Chidobe, Monde, and Mpisi among others. This restaurant also employs people from the villages who explain the culture of these villages to the diners.

In Hwange, some lodges have partnered with a Non-Governmental organisation in reducing poverty in the nearby rural community. The lodges who carry out village tours in the neighbouring Lupote community have partnered with a Non-governmental organisation which operates in the Hwange National Park to promote the protection of wild dogs from extinction have used their good rapport with community leaders to introduce the NGO to the community. Together the two organisations have lobbied for funds from donors to support school children by buying them bicycles and tuition fees as well as books.

Lodges have also adopted cultural groups from the local community to perform for tourists during evenings. This has reduced poverty by creating a source of income for the members participating in the cultural performances. Cabrini, (2002) identifies music, dance, customs, and village tours as some of the rural tourism products which a tourism organisation can adopt in working with local communities who have access to these and would take pride in showcasing them, at the same time earning an income from it. Ashley and Roe, (2001) emphasise that every pro-poor tourism strategy should aim at ensuring that the poor reap the net benefits from tourism. Although the initiatives currently being practiced by these tourism and hospitality organisations are small-scale in nature, they point towards a possible enlargement of the connexion in future between tourism and pro-poor development in Victoria Falls and Hwange. 
Access to electricity is one factor which can show the level of poverty in a given community. Some tour operators in Victoria Falls indicated that they have engaged tourists after village tours which raised awareness in the tourists about the nature of problems the community was facing. So far electricity has been connected at two primary schools. The availability of electricity at the schools has resulted in teachers preferring working at the schools and the schools have managed to retain good and qualified teachers for longer. Children can also study in the evening thus improving their chances of getting better grades.

Although the tourism organisations have adopted all the aforementioned strategies in helping the poor rural people in the nearby communities, research has shown that for a complete connection to exist between tourism and pro-poor development, net benefits from tourism have to accrue to the poor (Ashley \& Roe,2002, Scheyvens, 2001, Mafunzwaini \& Hugo, 2001). From the findings it is evident that pro-poor tourism benefits accrue to the poor through voluntary donations from tourism enterprises, employment of the poor people in low level positions and limited supply of products by the poor to tourism enterprises. For tourism to be completely pro-poor there is need for rural people to gain empowerment through involvement in decision making about tourism in their area, formation of small enterprises (UNWTO, 2005) and partnerships between them and local private tourism organisations. Lepp (2001) gives a good example of a true pro-poor initiative in Uganda where rural women run walking trails, village tours and park restaurants. In Nepal, SNV a donor agent has assisted rural people to start- up small enterprises in tourism, which after reaching sustainability run as private businesses owned by rural people (Ashley \& Boyd, 2005). In South Africa, in Makuleke and Manyeleti communities, the government of South Africa awarded the communities control over Game Reserves where private investors then come and get hunting concessions and remit fees to the community (Mafunzwaini \& Hugo, 2005). The situation in Victoria Falls and Hwange is still deficient of these attributes and therefore leaves a lot to be desired. The organisations could also look at other infrastructure including roads, clinics and clean water, since these are also variables considered when measuring poverty levels. So far, most of the organisations are concentrating on primary education and availability of teachers, which is a good starting point.

\section{Conclusion}

Although there is not yet any government commitment to ensure that tourism contributes to the alleviation of poverty in Zimbabwe, this research's findings show signs of an initial connection between tourism and poverty reduction. As the nature of tourists visiting the developing countries change and visitors become more interested in the welfare of the host communities, the tourism companies in Hwange and Victoria Falls have created a useful linkage to bring the most benefits of tourism to the poor. However, proponents of pro-poor tourism would advocate for better interventions which include employment of more local people in tourism jobs (which is currently difficult due to the lack of requisite skills among local communities), partnerships with locals and promotion of informal businesses and enhancing linkages between tourism enterprises and the poor people However, it would be prudent to note that the nature of interventions a tourism organisation can offer depends on the level of poverty within a specific community. What the organisations are currently doing is to address the most basic needs and upgrade the community to a better position for other interventions to be more meaningful. Generally the poverty intervention strategy that seems prominent among tourism businesses in Zimbabwe is volunteerism in the form of educational support from tourism and hospitality businesses. Volunteerism is noble but it does create problem of dependency rather than self-reliance. Poverty alleviation cannot be realized unless if the poor can be assisted to have the capability to run and manage tourism businesses and also have linkages with tourism enterprises. If the linkages between tourism and other sectors of the economy are increased a reduction of leakages from the local economy is witnessed. The fact that production and consumption of tourism services is simultaneous makes tourism have a higher potential for linkages with the rest of the local economy and thus contributes to poverty alleviation (Muhanna, 2007). The multi-faceted nature of tourism, allows for higher potential for linkages of tourism enterprises with other local enterprises within destination areas (Gartner, 2008). In Mauritius, Maldives, the Dominican Republic and other Caribbean islands proper linkage of tourism with the rest of the economy has brought with it dividends (Prats in Díaz Benavides, 2001 as cited in Muhanna 2007). It is therefore prudent to establish linkages in destination areas in a bid to increase the scale of poverty alleviation in the aforementioned communities under study.

Additionally from a few studies related to Sub-Saharan Africa show that the role of education in determining the movement into and out poverty is not such significant in rural areas (Diawara, 2011). This therefore means tourism and hospitality enterprises need to adopt approaches other than education in order to reduce rural poverty. 


\section{References}

Alexander, J., \& McGregor, J. (2000). Wildlife and Politics; CAMPFIRE in Zimbabwe. Journal of Development and Change, 31(1), 605-627. http://dx.doi.org/10.1111/1467-7660.00169

Ashley, C., \& Roe, D. (2010). Making tourism work for the poor: strategies and challenges in Southern Africa. Development Southern Africa Journal, 19(1).

Ashley, C., Haysom, G., Poultney, C., McNab, D., \& Harris, A. (2005). How to . . .? Brief 1: Boosting procurement from local businesses. Overseas Development Institute and Business Linkages in Tourism.

Ashley, C., Roe, D., \& Goodwin, H. (2001). Pro-poor tourism strategies; making tourism work for the poor. A review of experience; Pro-poor Tourism Report No. 1, London; Overseas Development Institute and International Institute for Environment and Development and Center for Hospitality and Tourism Development.

Blake, A., Arch, S. J., Sinclair, T. M., \& Teles, V. (2007). Tourism and Poverty Relief. Annals of Tourism Research, 35(1).

Chikwanha-Dzenga, A. B. (1999). Rural Folks- the neglected Lot of Zimbabwe. Journal of Social Development in Africa, 14(2), 39-49.

Chok, S., Macbeth, J., \& Warren, C. (2007). Tourism as a Tool for Poverty Alleviation: A Critical Analysis of 'Pro-Poor Tourism' and Implications for Sustainability'. Current Issues in Tourism, 10(2), 144-165. http://dx.doi.org/10.2167/cit303

Diawara, B. (2011). The role of education on poverty reduction in Senegal. Unpublished Paper.

Farrell, B., \& Twinning-Ward, L. (2005). Seven steps towards sustainability: Tourism in the context of new knowledge. Journal of Sustainable Tourism, 13(2), 109-122. http://dx.doi.org/10.1080/09669580508668481

Gartner, C. M. (2008). Tourism Development and Poverty Reduction: A Case Study from Nkhata Bay, Malawi. Msc; University of Waterloo.

Gerosa, V. (2003). Tourism: A Viable Option for Pro-Poor Growth in Africa? Vittorio Gerosa Expert Group Meeting Munyonyo Speke Resort Kampala Uganda 23-24 June 2003; Uganda, Kampala.

Goodwin, H. (2010). Tourism and Poverty Reduction. Annals of Tourism Research, 38(1), 339-340. http://dx.doi.org/10.1016/j.annals.2010.11.007

Hasler, R. (1999). An overview of the Social, Ecological and Economic Achievements and challenges of Zimbabwe's CAMPFIRE programme. International Institute for environment and Development; Evaluating Eden Series; Discussion Paper No. 3; London.

Kinsey, H. (2010). Poverty Dynamics in Rural Zimbabwe: The 30Years (Lost) 'war against Poverty'. Chronic Poverty Research Centre, University of Manchester.

Lepp, A. P. (2004). Tourism in a rural Ugandan Village: Impacts, local meaning and implications for development. University of Florida.

Logan, B. I., \& Mosely, W. G. (2002). The Ecology of Poverty Alleviation in Zimbabwe's Campfire. Geoforum, 33, 1-14. http://dx.doi.org/10.1016/S0016-7185(01)00027-6

Lurdi, E., \& Bird, K. (2007). Understanding Poverty. Retrieved from http://www.poverty-wellbeing.net

Mafunzwaini, \& Hugo. (2005). Unlocking the rural tourism potential of the Limpopo province of South Africa: some strategic guidelines. Development South Africa, 22, 2. http://dx.doi.org/10.1080/03768350500163048

Manjengwa, J., Kasirye, I., \& Matema, C. (2012). Understanding poverty in Zimbabwe: A sample survey in 16 Districts (2012); Paper prepared for presentation at the Centre for the Study of African Economies Conference 2012 "Economic Development in Africa". March 18-20, 2012; Oxford, United Kingdom.

Manwa, H. (2003). Wildlife -based tourism, ecology and sustainability. A tug-of-war among competing interests in Zimbabwe. The Journal of Tourism Studies, 14(2), 45-54.

Manwa, H. (2007). Is Zimbabwe ready to venture into the cultural tourism market? Development Southern Africa, 24(3), 465-474. http://dx.doi.org/10.1080/03768350701445558

Manyena, S. B. (2003). Missing the Tonga. The impact of Land Reform program in Binga district. African Institute of Agrarian Studies. 
Mbaiwa, J. (2005). Enclave tourism and its socio-economic impacts in the Okavango Delta, Botswana. Tourism Management, 26, 157-172. http://dx.doi.org/10.1016/j.tourman.2003.11.005

Mkono. (2010). The future of tourism in Zimbabwe: Towards Sustainability? The Journal of Tourism Analysis, $15,387-391$.

Morforth, M., \& Munt, I. (1998). Tourism and Sustainability: New tourism in the third world. Roundtable Series; Weaver Press, Harare.

Muchapondwa, E. (2001). An overview of Community-Based Wildlife Conservation in Zimbabwe. Goteborg University, Sweden.

Muhanna, E. (2007). Tourism Development Strategies and Poverty Elimination. Problems and Perspectives in Management, 5(1), 37-47.

Nyathi, D. (2012). An evaluation of poverty alleviation strategies implemented by Non-Governmental Organisations in Zimbabwe: A case of Binga Rural District. University of Fort Hare, South Africa.

Shaw, G., \& Williams, M. A. (1994). Critical Issues in Tourism: a geographical perspective. Blackwell Publishers Limited.

Spenseley, A., \& Seif, J. (2003). Strategies, Impacts and Costs of Pro-poor Tourism approaches in Southern Africa. PPT Working Paper Number 11; DFID; United Kingdom.

United Nations World Tourism Organization (UNWTO). (2005). Tourism, Microfinance and Poverty Alleviation. Madrid Spain, UNWTO.

United Nations. (1995, March). Report of World Summit for Social Development Copenhangen. UN, New York.

Zeng, B., \& Ryan, C. (2012). Assisting the Poor in China through Tourism Development: A review of research. Tourism Management, 33, 239-248. http://dx.doi.org/10.1016/j.tourman.2011.08.014 